\title{
Effects of suppression by a progesterone-releasing intravaginal device and subsequent induction by GnRH of the preovulatory LH surge on follicular function in PMSG/PG-treated heifers
}

\author{
P. L. A. M. Vos, M. M. Bevers, A. H. Willemse and \\ S. J. Dieleman \\ Department of Herd Health and Reproduction, Faculty of Veterinary Medicine, University of Utrecht, \\ Yalelaan 7, de Uithof, 3508 TD Utrecht, The Netherlands
}

\begin{abstract}
After synchronization of oestrus, normally cyclic heifers $(n=31)$ received $2500 \mathrm{iu}$ pregnant mares' serum gonadotrophin (PMSG) i.m. and had a progesterone-releasing intravaginal device (PRID) without the oestradiol capsule inserted on day 10 of the oestrous cycle and received $15 \mathrm{mg}$ prostaglandin (PG) i.m. $48 \mathrm{~h}$ later. PRIDs were removed $96 \mathrm{~h}$ after insertion and 16 heifers received $1.0 \mathrm{mg} \mathrm{GnRH}$ i.m. while the controls $(n=15)$ received $10 \mathrm{ml}$ saline i.m. All heifers were injected with anti-PMSG i.v. $10 \mathrm{~h}$ later. Peripheral blood concentrations of PMSG, progesterone, oestradiol and LH were compared. Ovaries were collected on death 7 days after the $\mathrm{GnRH}$ or saline injection and the number of corpora lutea counted. Heifers were considered to have responded well $\left(>60 \mathrm{pmol} \mathrm{l}^{-1}\right.$ ) or poorly $\left(<60 \mathrm{pmol} \mathrm{l}^{-1}\right)$ to superovulation on the basis of the oestradiol concentration $24 \mathrm{~h}$ after PG administration. During PRID treatment, LH concentrations remained at basal values. In the heifers treated with $\mathrm{GnRH}$, a single $\mathrm{LH}$ surge occurred $2.3 \pm 0.1 \mathrm{~h}$ (SD) after the $\mathrm{GnRH}$ injection with a maximum concentration of $14.6 \pm 2.3$ (SEM) $\mu \mathrm{g} \mathrm{l}^{-1}$ and a duration of $6-8 \mathrm{~h}$. In 12 of the 15 control heifers, LH concentrations remained low (range $0.10-1.94 \mu \mathrm{g} \mathrm{l}^{-1}$ ) during the $72 \mathrm{~h}$ following the saline injection; three controls showed a spontaneous LH surge at 18, 23 and $23 \mathrm{~h}$ after the saline injection, respectively, with a maximum concentration of 6.0-12.5 $\mu \mathrm{g} \mathrm{l}^{-1}$ and a duration of 10-12 h. The oestradiol concentration increased continuously during PRID treatment until the injection of $\mathrm{GnRH}$ or saline, when it was four times higher in the heifers that responded well than in the heifers that responded poorly. It decreased sharply $6 \mathrm{~h}$ after $\mathrm{GnRH}$ indicating that the follicles still responded normally to a preovulatory $\mathrm{LH}$ signal, whereas in control heifers a similar decrease took place $4 \mathrm{~h}$ later following anti-PMSG treatment. In the GnRH-treated heifers, the heifers responding well showed a significantly higher number of corpora lutea than did the animals showing a poor response, $16.4 \pm 2.2(n=9)$ and $5.4 \pm 1.4(n=7)$, respectively. Five of the 12 control heifers without an immediate LH surge showed a single corpus luteum, and seven heifers did not have a corpus luteum. For the three controls with an LH surge, $33.0 \pm 8.5$ corpora lutea were observed. In conclusion, the preovulatory LH signal can be effectively postponed in PMSG/PG-superovulated heifers using a PRID. However, the PRID treatment has to be followed by GnRH to obtain the LH surge at a defined time of preovulatory follicular development. Follicular function with regard to oestradiol secretion and the potential to ovulate remains unchanged.
\end{abstract}

\section{Introduction}

Even under standard conditions with respect to breed, nutritional status of donor cattle, management factors and seasonal influences (Hasler et al,, 1987; Breuel et al., 1991), superovulation is still highly variable in the response of the follicular population to exogenous gonadotrophins such as pregnant mares' serum gonadotrophin (PMSG) and FSH (Monniaux et al., 1984; Boland et al., 1991). Thus the number and quality of transferable embryos is unpredictable, and a relatively high proportion of donors fail to produce any transferable embryos (for review, see Downloaded from Bioscientifica.com at 04/26/2023 08:40:38AM
and Fertility Ltd
via free access 
Armstrong, 1993). The cause of this variability is mainly the different status of the recruited follicles at the time superovulatory treatment is started (Moor et al., 1984). In particular, the presence or absence of a dominant follicle is important as such a follicle probably suppresses the number of follicles stimulated resulting in a reduced ovulation rate (Guilbault et al., 1991; Huthinen et al., 1992). Deviations from the normal pattern of preovulatory follicular development may occur during the following stages: (1) at primary stimulation, between injections of PMSG and prostaglandin (PG); (2) selection and growth, between PG injection and the endogenous $\mathrm{LH}$ peak; or (3) at final maturation, after the LH peak and until ovulation (Dieleman and Bevers, 1993).

During the period of final maturation, discrepancies between the maturational stage of the follicles, that is, the status of the follicular wall and steroidogenesis, and their concomitant oocytes can be observed (Hyttel et al., 1991). Neutralization of PMSG at the onset of final maturation, that is, immediately after the preovulatory LH surge, reduces the proportion of follicles with an abnormally high oestradiol concentration in the follicular fluid shortly before ovulation (Dieleman et al., 1988), resulting in an increase of the number of ovulations and transferable embryos (Dieleman et al., 1993). Although neutralization apparently improves the steroidal microenvironment of the oocyte, De Loos et al. (1991) demonstrated that a substantial number of follicles still show intrafollicular asynchrony. This intrafollicular asynchrony may originate during the earlier stages of preovulatory follicular development. During the period of selection and growth preceding the endogenous $\mathrm{LH}$ surge, a difference in developmental stage within the cohort of stimulated follicles appears to be present, indicating an interfollicular asynchrony (Vos et al., 1994). Neutralization of PMSG at the ascending limb of the preovulatory LH surge markedly reduces the number of ovulating follicles. The proportion of follicles that are in an advanced maturational stage of development probably evoke the preovulatory $\mathrm{LH}$ surge at too early a stage for the remainder of the induced follicle population. Whether the LH surge can be postponed temporarily to increase the number of mature follicles at the onset of final maturation is not known. In non-stimulated cows, treatment with progesterone inhibits the mechanisms leading to the release of the preovulatory LH surge by suppressing $\mathrm{LH}$ pulse frequency (Roche and Ireland, 1981). Although in PMSGstimulated heifers, LH pulse frequency is reduced after the onset of luteal regression during preovulatory follicular development (Bevers et al., 1989), the LH surge occurs about $44 \mathrm{~h}$ after the onset of luteal regression (Bevers and Dieleman, 1987). It is, therefore, unclear whether treatment with a progesterone-releasing intravaginal device (PRID) will be sufficient to prevent the LH surge in PMSG-stimulated heifers, particularly when the response to the gonadotrophin treatment results in a large number of preovulatory follicles. To obtain temporary postponement of the LH surge in PMSGstimulated heifers it can be assumed that induction of an LH surge is required since in non-stimulated cows, the LH surge occurs from $48 \mathrm{~h}$ after removal of the PRID (Kojima et al., 1992).

We investigated whether suppression with PRID and subsequent induction of a preovulatory LH surge with $\mathrm{GnRH}$ is possible in PMSG/PG-stimulated heifers and the effects of this treatment on follicular function.

\section{Materials and Methods}

\section{Animals}

The study was performed from September to December 1991 using Holstein-Friesian heifers $(n=31)$, aged 18-22 months, which were randomly assigned to experimental or control groups. The animals were housed indoors in groups of five under conditions that ensure normal ovarian cyclicity, and were fed silage and concentrate. Oestrous cycles were synchronized before the experiments with Crestar (Intervet International BV, Boxmeer) which includes a $3 \mathrm{mg}$ norgestomet ear implant and an i.m. injection of $5 \mathrm{mg}$ oestradiol valerate and $3 \mathrm{mg}$ norgestomet given at the time of implant insertion. The implants were removed after 9 days. Superovulation was initiated 10 days after the observed synchronized oestrus by an i.m. injection of 2500 iu PMSG (Folligon, Intervet International $\mathrm{BV}$ ) and $15 \mathrm{mg}$ prostaglandin (PG; Prosolvin, Intervet International BV) i.m. $48 \mathrm{~h}$ later. All animals received a PRID ( $1.55 \mathrm{~g}$ progesterone; Sanofi BV, Maassluis) without the oestradiol benzoate-containing capsule at the time of the PMSG injection. When the PRIDs were removed $96 \mathrm{~h}$ after insertion, heifers in the experimental group $(n=16)$ received $1.0 \mathrm{mg}$ GnRH (Fertagyl; Intervet International BV) i.m. in $10 \mathrm{ml}$ saline to induce a preovulatory $\mathrm{LH}$ surge. Heifers serving as controls $(n=15)$ were injected with $10 \mathrm{ml}$ saline i.m. $(0.9 \% \mathrm{NaCl}$ solution). All heifers received anti-PMSG i.v. (Neutra-PMSG, Intervet International) $10 \mathrm{~h}$ after $\mathrm{GnRH}$ or saline administration in a dose $(5 \mathrm{ml})$ sufficient to neutralize 2500 iu PMSG within $1 \mathrm{~h}$ (Dieleman and Bevers, 1987).

Heparinized blood samples were collected from the jugular vein once a day from day 0 (oestrus) until day 10, every $6 \mathrm{~h}$ from the injection of PMSG until the PG injection, and then every $2 \mathrm{~h}$ from the administration of PG until $30 \mathrm{~h}$ after PG and, finally, every hour from $18 \mathrm{~h}$ before until $72 \mathrm{~h}$ after the injection of saline or GnRH. Progesterone, oestradiol and LH concentrations were determined from these samples.

The response to superovulation is highly variable within and between animals (Armstrong, 1993). In cows responding to superovulation with many follicles, the preovulatory LH surge usually occurs well within $44 \mathrm{~h}$ of the PG injection, and in cows with a poor response, the $\mathrm{LH}$ surge occurs more than $44 \mathrm{~h}$ after PG injection (Bevers and Dieleman, 1987). Since, in the present study, the PRIDs were removed $48 \mathrm{~h}$ after the PG injection, it could be expected that the eventual suppression of the $\mathrm{LH}$ surge would occur only in those heifers responding well to superovulation. Retrospective to treatment, heifers were grouped as good or poor responders on the basis of the plasma concentration of oestradiol $24 \mathrm{~h}$ after the PG injection. Data from the good responders $\left(>60 \mathrm{pmol} \mathrm{l}^{-1}\right)$ and poor responders $\left(<60 \mathrm{pmol} \mathrm{I}^{-1}\right)$ were studied separately. The concentration of $60 \mathrm{pmol} \mathrm{l}^{-1}$ was selected as this is three times the concentration $24 \mathrm{~h}$ after the onset of luteolysis in normally cyclic heifers (Dieleman et al., 1986), at which time the PRID treatment has not yet affected follicular function.

Downloaded from Bioscientifica.com at 04/26/2023 08:40:38AM 


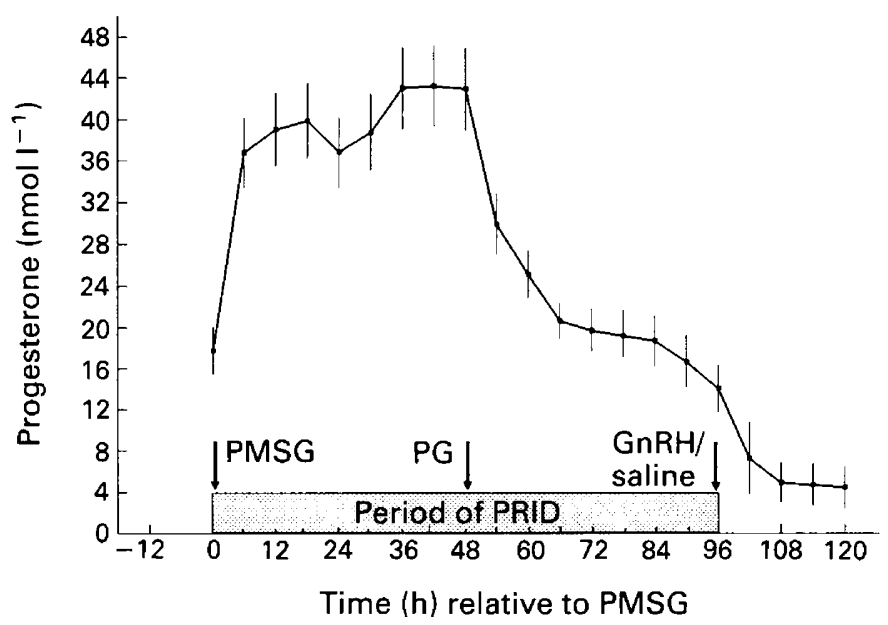

Fig. 1. Progesterone concentrations (mean \pm SEM) in peripheral blood of pregnant mares' serum gonadotrophin (PMSG)-superovulated heifers $(n=31)$ during and after the period of insertion of a progesteronereleasing intravaginal device (PRID). The arrows indicate the i.m. injection of 2500 iu PMSG, $15 \mathrm{mg}$ prostaglandin (PG) and $1.0 \mathrm{mg} \mathrm{GnRH}$ or $10 \mathrm{ml}$ saline.

The ovaries were recovered at death 7 days after treatment with GnRH or saline and the number of corpora lutea was determined.

\section{Radioimmunoassay of PMSG, LH, progesterone and oestradiol}

Concentrations of PMSG were estimated in duplicate in one assay with a homologous double-antibody radioimmunoassay method as described by Dieleman and Bevers (1987). Before assay, samples were incubated with donkey antimouse antibody-coated cellulose suspension, to remove the monoclonal antibody against PMSG and its complexes with PMSG. The lowest detectable amount of PMSG was $0.3 \mu \mathrm{g} \mathrm{I}^{-1}$ plasma. The intra-assay coefficient of variation was $7.1 \%$.

Concentrations of progesterone and oestradiol were estimated by validated solid phase ${ }^{125} \mathrm{I}$ radioimmunoassay methods (Coat-A-Count TKPG and TKE, respectively; Diagnostic Products Corporation, Los Angeles, CA) according to the manufacturer's instructions with slight modifications as described previously (Dieleman and Bevers, 1987). The sensitivity was $0.15 \mathrm{nmol} \mathrm{l}^{-1}$ and $7.5 \mathrm{pmol} \mathrm{l}^{-1}$, respectively; the intra-assay coefficients of variation were 8 and $9 \%$ respectively, and the interassay coefficients of variation 11 and $8.9 \%$, respectively.

Concentrations of $\mathrm{LH}$ were estimated by a validated radioimmunoassay method as described by Dieleman et al. (1986). The intra- and interassay coefficients of variation were less than $9 \%$. The sensitivity was $0.4 \mu \mathrm{g} \mathrm{NIH-LH-B4} \mathrm{l}^{-1}$. Crossreactivity of PMSG (highly purified PMSG PM23-2P; Intervet International) was $0.2 \%$.

\section{Statistical analysis}

Student's $t$ test was used to compare the mean of two samples. Correlation was studied with a least squares linear regression test. Data were considered to be significantly different at $P<0.05$.

\section{Results}

\section{PMSG and progesterone concentrations}

The mean concentration of PMSG in peripheral blood $2 \mathrm{~h}$ before administration of anti-PMSG was $5.0 \pm 1.6 \mu \mathrm{g} \mathrm{l}^{-1}$ (SD; $n=31$ ). The concentration of PMSG showed a marked decrease in all animals within $1 \mathrm{~h}$ of administration of antiPMSG to basal values less than or equal to the detection limit of the radioimmunoassay method.

The mean concentration of progesterone in peripheral blood on day 10 (that is, before PMSG administration) was $17.7 \pm$ $2.3 \mathrm{nmol} \mathrm{1}^{-1}$ (SEM; $n=31$ ), increased to $42.9 \pm 4.0 \mathrm{nmol} \mathrm{l}^{-1}$ on day 12 , and then decreased to $19.7 \pm 2.0 \mathrm{nmol} \mathrm{I}^{-1} 24 \mathrm{~h}$ after PG. Thereafter, the concentration was maintained at $17.7 \pm 1.7 \mathrm{nmol} \mathrm{l}^{-1}$ until withdrawal of PRID $48 \mathrm{~h}$ after PG, and decreased to a value less than $4.5 \mathrm{nmol} 1^{-1} 24 \mathrm{~h}$ after removal of PRID (Fig. 1).

\section{LH suppression and induction}

During the $48 \mathrm{~h}$ of PRID treatment after the injection of PG, the $\mathrm{LH}$ concentration in peripheral blood remained low (range $\left.0.10-1.29 \mu \mathrm{g} \mathrm{l}^{-1}\right)$ in all heifers $(n=31)$ and no LH surge was detected until the PRID was removed. In the subsequent $72 \mathrm{~h}$ one single LH surge was observed in the GnRH-treated heifers ( $n=16) 2.3 \pm 0.1 \mathrm{~h}$ (SD) after injection of $\mathrm{GnRH}$, with a maximum concentration of $14.6 \pm 2.3 \mu \mathrm{g} \mathrm{l}^{-1}$ and a duration of 6-8 $\mathrm{h}$ (Fig. 2). In the corresponding $72 \mathrm{~h}$ the $\mathrm{LH}$ concentration remained low (range $0.1-1.94 \mu \mathrm{g} \mathrm{I}^{-1}$ ) in 12 of the 15 control heifers and the remaining three control heifers showed 


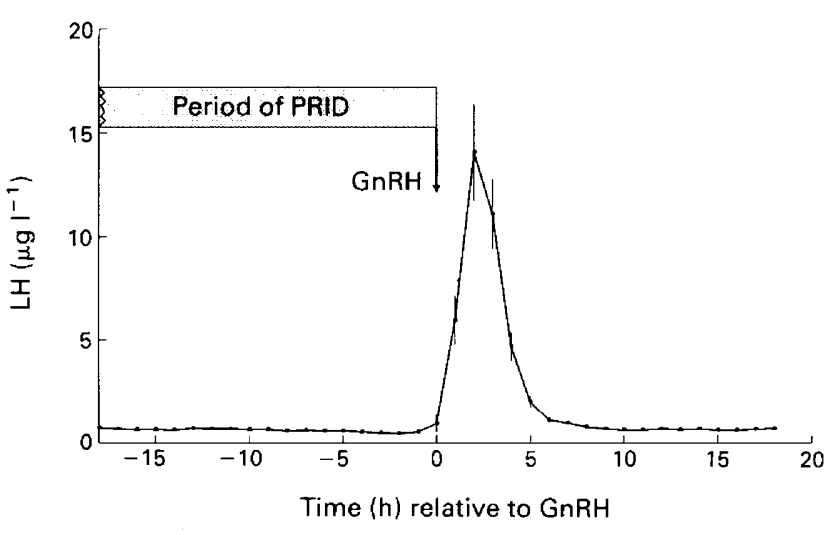

Fig. 2. $\mathrm{LH}$ concentration (mean \pm SEM) in peripheral blood of GnRHtreated heifers $(n=16)$ before and after i.m. injection $(\downarrow)$ of $1.0 \mathrm{mg}$ GnRH administered simultaneously with the removal of a progesterone-releasing intravaginal device (PRID) during superovulation induced by treatment with pregnant mares' serum gonadotrophin and prostaglandin.

spontaneous LH surges. The LH surges occurred 18, 23 and $23 \mathrm{~h}$ after injection of saline, respectively, with a maximum concentration of $6-12.5 \mu \mathrm{g} \mathrm{I}^{-1}$ and a duration of $10-12 \mathrm{~h}$.

\section{Follicular function}

Oestradiol concentration. In most animals, the mean oestradiol concentration $\left(19.2 \pm 2.2\right.$ pmol l$\left.^{-1} ; n=31\right)$ in peripheral blood on day 10 (before PMSG administration) increased significantly after PMSG administration. During PRID treatment, and in particular during the period between completion of luteolysis $24 \mathrm{~h}$ after PG and withdrawal of the intravaginal device, there was a continuous increase in oestradiol concentration until the LH surge in GnRH-treated heifers or until the administration of anti-PMSG in the saline-treated animals (Fig. 3). The oestradiol concentration was significantly higher in the heifers responding well to superovulatory treatment than in the poor responders (Table 1 ). In the GnRH-treated heifers, the oestradiol concentration decreased significantly to basal values beginning $4 \mathrm{~h}$ after the peak of the $\mathrm{GnRH}$-induced $\mathrm{LH}$ surge. In the 12 of 15 control heifers without an LH surge, the oestradiol concentration decreased immediately after the injection of anti-PMSG. The decrease in oestradiol concentration in GnRHor saline-treated heifers that responded well to superovulation treatment are illustrated (Fig. 4). In the three control heifers showing a spontaneous LH surge, the oestradiol concentration showed a temporary decrease of $70-80 \%$ immediately after the injection of anti-PMSG, increased until the preovulatory $\mathrm{LH}$ peak and then returned to basal values $4 \mathrm{~h}$ later.

Ovarian status. Examination of the ovaries 7 days after the GnRH or saline injection showed that there were few large anovulatory follicles $(15-30 \mathrm{~mm}$ diameter) that were partially luteinized $(0.4 \pm 0.2 ; n=31)$. In the GnRH-treated heifers, the animals responding well to superovulation treatment had significantly more corpora lutea than did the poor responders, $16.4 \pm 2.2(n=9)$ versus $5.4 \pm 1.4(n=7)$, respectively. The number of corpora lutea did not correlate with the maximum concentration of the LH surge $(n=16 ; r=-0.07$; $P>0.05$ ). Five of the 12 control heifers without an LH surge showed a single corpus luteum, which was small and red, and seven heifers had no corpus luteum; no differences were observed between good and poor responders in this respect. For the three control heifers with spontaneous LH surge, $33.0 \pm 8.5$ corpora lutea were observed; these heifers had been classified as good responders.

\section{Discussion}

The patterns of progesterone concentration in peripheral blood are in general agreement with those reported for superovulated cattle by Saumande (1980); Yadav et al. (1986) and Bevers and Dieleman (1987), taking into account the release of progesterone by the PRID. Since luteolysis in PMSG-treated cows is complete 24-30 h after PG administration (Dieleman and Bevers, 1987), the increased progesterone concentration resulting from PG treatment and lasting until withdrawal of the intravaginal device indicates that PRIDs can be successfully used to sustain mid-luteal progesterone concentrations in the absence of a corpus luteum for a discrete period. After the onset of luteolysis, no LH surge was observed in any of the heifers during the period of high progesterone concentration, indicating that PRID treatment effectively suppressed the preovulatory LH surge. The suppression of the LH surge until $48 \mathrm{~h}$ after PG treatment was particularly evident in the heifers responding well to superovulation in that PMSG treatment had induced many preovulatory follicles. In PMSG-superovulated heifers, kept under similar conditions as those in the present work, the preovulatory LH peak occurred $43.9 \pm 7.9 \mathrm{~h}$ (SD) after PG injection; this interval was reduced as the number of preovulatory follicles increased (Bevers and Dieleman, 1987).

All 16 experimental heifers showed a single LH surge $2.3 \mathrm{~h}$ after GnRH treatment, strongly suggesting that in the GnRHtreated heifers the observed LH surge was exclusively due to the pituitary response to $\mathrm{GnRH}$. This is further supported by the observation that in most of the control heifers no LH surge was detected. An LH surge occurred in only three of the saline-treated heifers, at least $18 \mathrm{~h}$ after the injection of saline, that is, $66 \mathrm{~h}$ after PG. The amplitude and duration of the surge in the experimental animals are similar to those of spontaneous LH surges seen in PMSG/PG-stimulated heifers and cows (Bevers and Dieleman, 1987; Dieleman and Bevers, 1987). Comparison of the pattern of LH secretion in the GnRHtreated heifers with those of the control heifers demonstrates that the $\mathrm{GnRH}$ injection is necessary to obtain a preovulatory $\mathrm{LH}$ surge at the time of completion of follicle selection and initiation of preovulatory follicular growth.

Follicular function appeared to be unaffected by the high progesterone concentration, as the oestradiol concentration showed a marked increase after luteolysis and continued to increase throughout the period of PRID treatment. The pattern of increase in oestradiol concentration is similar to that seen in superovulated cows (Saumande, 1980; Bevers and Dieleman, 1987). The preovulatory follicles apparently acquired the necessary characteristics to respond to the induced LH surge, as indicated by the rapid decline in peripheral oestradiol concentration beginning approximately $4 \mathrm{~h}$ after the peak of the $\mathrm{LH}$ Downloaded from Bioscientifica.com at 04/26/2023 08:40:38AM 

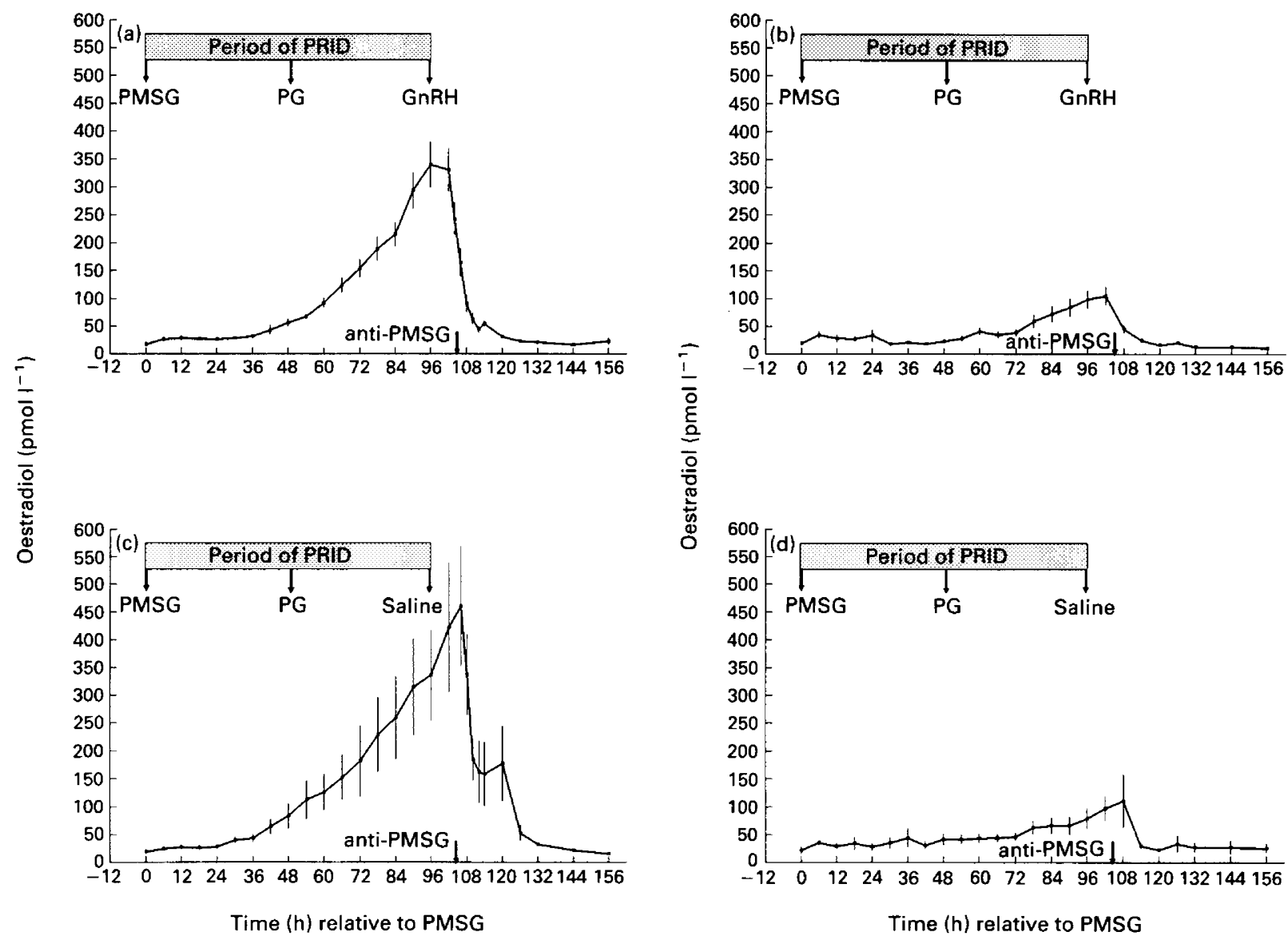

Fig. 3. Oestradiol concentration (mean \pm SEM) in peripheral blood of heifers during superovulation induced by treatment with pregnant mares' serum gonadotrophin (PMSG) and prostaglandin (PG) before and after i.m. injection ( $\downarrow$ ) of (a) and (b) $1.0 \mathrm{mg}$ GnRH or (c) and (d) $10 \mathrm{ml}$ saline administered at the same time as removal of a progesterone-releasing intravaginal device (PRID). Heifers were classed as having responded well $((\mathrm{a}) n=9)$ and $((\mathrm{c}) n=9)$ or poorly $((\mathrm{b}) n=7)$ and $((\mathrm{d}) n=5)$ to superovulation on the basis of a concentration of 60 pmol oestradiol $\mathrm{I}^{-1} 24 \mathrm{~h}$ after PG treatment.

Table 1. Oestradiol concentrations ( $\mathrm{pmol}^{-1}$ ) at specific times during treatment with a progesterone-releasing intravaginal device in peripheral blood of heifers in which superovulation has been induced by pregnant mares' serum gonadotrophin and prostaglandin (PG) and which were injected with GnRH or saline $48 \mathrm{~h}$ after PG treatment

Treatment groups

$-48$

Time (h) relative to $P G$ treatment

24

48

$\begin{array}{ll}\text { GnRH } & \\ \quad \text { Good* }^{*}(n=9) & 17.8 \pm 4.1 \\ \text { Poor* }(n=7) & 19.0 \pm 3.2 \\ \text { Saline } & \\ \quad \text { Good* }(n=9) & 19.3 \pm 4.7 \\ \text { Poor* }(n=6) & 21.6 \pm 6.7\end{array}$

$$
\begin{gathered}
153.7 \pm 16.0^{\mathrm{a}} \\
39.0 \pm 5.9^{\mathrm{b}} \\
181.5 \pm 63.5^{\mathrm{a}} \\
46.6 \pm 6.6^{\mathrm{b}}
\end{gathered}
$$

$339.8 \pm 41.8^{\mathrm{a}}$

$98.2 \pm 15.9^{b}$

$335.8 \pm 81.7^{\mathrm{a}}$

$78.8 \pm 17.7^{\mathrm{b}}$

Values are means \pm SEM; numbers of heifers in parentheses. Values within a column with different superscripts are significantly different.

${ }^{*}$ Heifers were classed as good (oestradiol concentration $>60 \mathrm{pmol} \mathrm{I}^{-1} 24 \mathrm{~h}$ after PG injection) or poor $\left(<60\right.$ pmol $\left.1^{-1}\right)$ responders to superovulation treatment.

surge. This is similar to the decline reported previously for PMSG-superovulated heifers and cows (Dieleman and Bevers, 1987; Callesen et al., 1990). In the control animals, the oestradiol concentration did not decrease at the corresponding time but decreased rapidly to basal values immediately after the injection of anti-PMSG. This decrease is considered as being due to the loss of FSH-like support by PMSG, thus terminating granulosa aromatase activity, since the rate of decrease was much higher than that reported for heifers without anti-PMSG treatment and without an LH surge (Bevers and Dieleman, Downloaded from Bioscientifica.com at 04/26/2023 08:40:38AM 


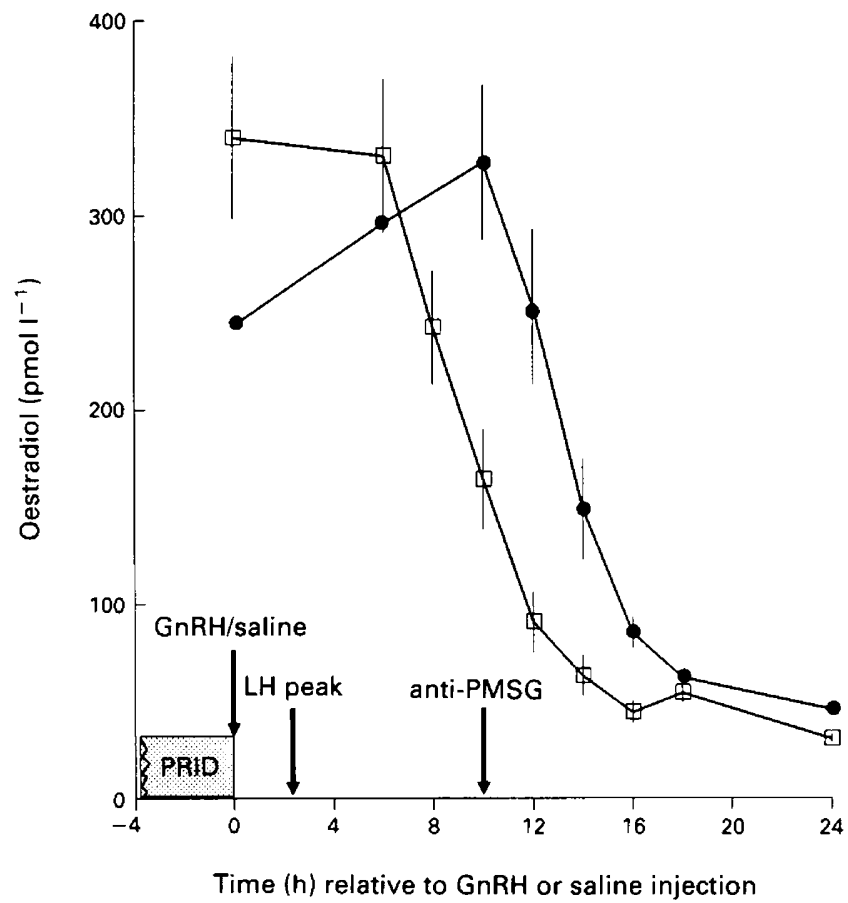

Fig. 4. Oestradiol concentration (mean \pm SEM) in peripheral blood of heifers, responding well to superovulation induced by pregnant mares' serum gonadotrophin and prostaglandin, relative to administration $(\downarrow)$ i.m. of $1.0 \mathrm{mg} \mathrm{GnRH} \mathrm{(} \square ; n=9$ ) or $10 \mathrm{ml}$ saline $(0 ; n=6)$ at the same time as removal of a progesterone-releasing intravaginal device (PRID). All heifers received one dose of anti-PMSG i.v. $10 \mathrm{~h}$ after injection of GnRH or saline. LH peak: time the maximum of the induced LH surge was observed.

1987). It can be argued, therefore, that the reason for the immediate decrease in oestradiol concentration in the salinetreated heifers is different from that responsible for the delayed decrease in the GnRH-treated heifers. In the latter case, the LH surge probably inhibits thecal androstenedione synthesis depleting the precursor for the membrana granulosa aromatase as in preovulatory follicles in normal cyclic cows (Dieleman et al., 1983). Whether GnRH affects final follicular and oocyte maturation cannot be concluded from the present study. Petr et al. (1991) reported that GnRH affects neither follicular steroid concentrations nor the nuclear stage of the oocyte. However, Petr et al. (1991) injected GnRH at a fixed time after PG treatment, that is, at about the time of the spontaneous LH surge, regardless of the stage of follicular development.

The ability to ovulate was apparently unaffected by the superovulatory procedure used. The number of corpora lutea on day 7 after superovulation for the GnRH-treated heifers responding well to superovulation is similar to that reported previously for PMSG/anti-PMSG-treated heifers and cows (Dieleman and Bevers, 1987; Bevers et al., 1993). It is obvious that in the majority of the control animals multiple ovulations did not occur, as in the saline-treated heifers an LH peak did not occur during the 5 days after the PG injection. After this period, it is possible that a new preovulatory follicle developed in some of the control animals, as in these heifers a single corpus luteum was present which probably resulted from a recent ovulation. For the three control heifers with multiple ovulations, it is possible that a substantial number of preovulatory follicles did not require further PMSG support after PMSG neutralization.

GnRH has been used before in PMSG- and FSHsuperovulation protocols to increase the number of transferable embryos. Different GnRH preparations have been administered at various times relative to the onset of oestrus or to the injection of PG (36-54 h after PG treatment) that is, at about the time the spontaneous LH surge was expected, either for the practical purpose of synchronization of the cows with regard to the ovulation period (Foote et al., 1989; Voss et al., 1989) or to enhance the release of $\mathrm{LH}$, on the assumption that the spontaneous $\mathrm{LH}$ surge would be insufficient to induce ovulation of mature oocytes of all stimulated follicles (Guay and Bedoya, 1981; Wubishet et al., 1986). Although improvement of oocyte quality at ovulation (Laurinćík et al., 1991) and embryo yield (Wubishet et al., 1986) has occasionally been observed, the effects of $\mathrm{GnRH}$ treatment are highly variable (Savage et al., 1987; Lange et al., 1989; Prado Delgado et al., 1989) and sometimes negative (Walton and Stubbings, 1986). This variability may be related to a limited increase in $\mathrm{LH}$ concentration since Walton and Stubbings (1986) observed that GnRH treatment affected LH concentration in only $20 \%$ of cows. Moreover, in the present study no correlation was observed between the amplitude of the LH surge and the number of corpora lutea. However, a more important factor may be the timing of the induced LH surge relative to the stage of follicular development. Since the interval between injection of PG and the spontaneous LH surge varies considerably (Bevers and Dieleman, 1987), the GnRH-induced LH surge will have been evoked too early or too late during follicular development in many of the cows. In the present study, GnRH was administered at a specific stage of follicular development when it was presumed that an optimum proportion of the stimulated preovulatory follicles had acquired the characteristics necessary to respond to the $\mathrm{LH}$ surge. It is not clear, however, whether postponement of the LH surge by PRID treatment reduced interfollicular asynchrony, resulting in an increase in the number of mature follicles at the time of the $\mathrm{LH}$ surge, since the number of corpora lutea in the heifers responding well to superovulation treatment was similar to that reported previously for PMSG/anti-PMSG-treated heifers (Dieleman and Bevers, 1987). Rieger et al. (1990) observed that delay of the LH signal by an LHRH-antagonist, followed by injection of hCG $48 \mathrm{~h}$ after PG treatment, improved the proportion of transferable embryos, which may indicate that the number of mature follicles had been increased at the onset of final maturation.

In conclusion, the preovulatory LH signal can be effectively postponed in PMSG/PG-superovulated heifers using a PRID; however, PRID treatment has to be followed by GnRH treatments to obtain an $\mathrm{LH}$ surge at a defined time of preovulatory follicular development. Follicular function with regard to oestradiol secretion and potential to ovulate remained unchanged.

The authors wish to thank D. M. Blankenstein and A. V. P. van de Poll for the technical assistance and performing the radioimmunoassays and S. H. J. Mook, J. H. M. Lutz and their assistants for tending the animals and taking the blood samples.

Downloaded from Bioscientifica.com at 04/26/2023 08:40:38AM 


\section{References}

Armstrong DT (1993) Recent advances in superovulation of cattle Theriogenology 39 7-24

Bevers MM and Dieleman SJ (1987) Superovulation of cows with PMSG: variation in plasma concentration of progesterone, oestradiol, LH, cortisol, prolactir and PMSG and in number of preovulatory follicles Animal Reproduction Science 15 37-52

Bevers MM, Dieleman SJ, van Tol HTM, Blankenstein DM and van den Broek J (1989) Changes in pulsatile secretion patterns of LH, FSH, progesterone, androstenedione and oestradiol in cows after superovulation with PMSG Jourmal of Reproduction and Fertility 87 745-754

Bevers MM, Dieleman SJ, Gielen JTh, Wurth YA, Janszen BPM, van de Broek J and Willemse AH (1993) Yield of embryos in PMSG-superovulated cows treated with anti-PMSG six or 18 hours after the peak of luteinising hormone The Veterinary Record 132 186-189

Boland MP, Goulding D and Roche JF (1991) Alternative gonadotrophins for superovulation in cattle Theriogenology 35 5-17

Breuel KF, Baker RD, Butcher RL, Townsend EC, Inskeep EK, Dailey RA and Lerner SP (1991) Effects of breed, age and dosage of follicle stimulating hormone on the superovulatory response of beef cattle Theriogenology 36 241-255

Callesen H, Greve T, Hyttel P, Bak A, Gotfredsen P and Holm P (1990) Preovulatory plasma estradiol-17 $\beta$ concentrations and ovulation rates in PMSG/anti-PMSG treated heifers Theriogenology 34 251-258

De Loos FAM, Bevers MM, Dieleman SJ and Kruip ThAM (1991) Follicular and oocyte maturation in cows treated for superovulation Theriogenology 35 537-546

Dieleman SJ and Bevers MM (1987) Effects of monoclonal antibody against PMSG administered shortly after the preovulatory LH surge on time and number of ovulations in PMSG/PG-treated cows Journal of Reproduction and Fertility 81 533-542

Dieleman SJ and Bevers MM (1993) Folliculogenesis and oocyte maturation in superovulated cattle Molecular Reproduction Development 38 271-273

Dieleman SJ, Bevers MM, Poortman J and van Tol HTM (1983) Steroid and pituitary hormone concentrations in the fluid of preovulatory bovine follicles relative to the peak of LH in the peripheral blood Joumal of Reproduction and Fertility $69641-649$

Dieleman SJ, Bevers MM, van Tol HTM and Willemse AH (1986) Peripheral plasma concentrations of oestradiol, progesterone, cortisol, LH and prolactin during the oestrous cycle in the cow with emphasis on the peri-oestrous period Animal Reproduction Science 10 275-292

Dieleman SJ, Bevers MM, Kruip ThAM, van Tol HTM and Blankenstein DM (1988) Steroid profiles and micromorphology of the follicle population before ovulation in PMSG-superovulated cows with or without monoclonal anti-PMSG administered shortly after the preovulatory LH peak Proceedings of 11th Intermational Congress on Animal Reproduction and A.I. Dublin II 154

Dieleman SJ, Bevers MM, Vos PLAM and De Loos FAM (1993) PMSG/ anti-PMSG in cattle: a simple and efficient superovulatory treatment? Theriogenology 39 25-41

Foote RH, Allen SE and Henderson B (1989) Buserelin in a superovulatory regimen for Holstein cows. II. Yield and quality of embryos in commercial herds Theriogenology 31 385-392

Guay P and Bedoya M (1981) Effects of GnRH on blood serum hormone concentrations, ovulation rates and embryo production in lactating cows treated with PMSG Canadian Joumal of Comparative Medicine 45 352-356

Guilbault LA, Grasso F, Lussier JG, Rouillier P and Matton P (1991) Decreased superovulatory responses in heifers superovulated in the presence of a dominant follicle Journal of Reproduction and Fertility 91 81-89
Hasler JF, McCauley AD, Lathrop WF and Foote RH (1987) Effect of donorembryo-recipient interactions on pregnancy rate in a large-scale bovine embryo transfer program Theriogenology 27 139-168

Huthinen M, Rainio V, Aalto J, Bredback P and Mäki-Tanila A (1992) Increased ovarian responses in the absence of a dominant follicle in superovulated cows Theriogenology 37 457-463

Hyttel P, Callesen H, Greve T and Schmidt M (1991) Oocyte maturation and sperm transport in superovulated cattle Theriogenology 35 91-108

Kojima N, Stumpf TT, Cupp AS, Werth LA, Roberson MS, Wolfe MW, Kittok RJ and Kinder JE (1992) Exogenous progesterone and progestins as used in estrous synchrony regimens do not mimic the corpus luteum in regulation of luteinizing hormone and 17 $\beta$-oestradiol in circulation of cows Biology of Reproduction 47 1009-1017

Lange W, Koppitz G and Winkler L (1989) Untersuchungen zum Einfluss von Gn-RH auf den Superovulationseffekt nach PMSG-Behandlung bei Masthybridfärsen Monatshefte für Veterinär Medizin 44 414-417

Laurinčík J, Pícha J, Píchová D and Pivko J (1991) Effect of LH-RH on meiotic maturation of preovulatory oocytes in superovulated heifers Animal Reproduction Science 25 189-197

Monniaux D, Mariana JC and Gibson WR (1984) Action of PMSG on follicular populations in the heifer Journal of Reproduction and Fertility 70 243-253

Moor RM, Kruip ThAM and Green D (1984) Intraovarian control of folliculogenesis; limits to superovulation? Theriogenology 21 103-116

Petr J, Tománek J, Fulka Jr J, Míka J and Jilek F (1991) Effects of GnRH on preovulatory endocrinology and oocyte maturation in PMSG-superovulated cows Animal Reproduction Science 24 37-52

Prado Delgado AR, Elsden RP and Seidel GE, Jr (1989) Effects of GnRH on superovulated cattle Theriogenology 31 317-321

Rieger D, Walton JS, Johnson WH and Coy DH (1990) The effect of treatment with an LHRH antagonist on the quality of Day-7 embryos collected from superovulated Holstein heifers Theriogenology 33207 abstract

Roche JF and Ireland JJ (1981) The differential effect of progesterone on concentrations of luteinizing hormone and follicle stimulating hormone in heifers Endocrinology 108 568-572

Saumande J (1980) Concentrations of luteinizing hormone, oestradiol-17 $\beta$ and progesterone in the plasma of heifers treated to induce superovulation Journal of Endocrinology 84 425-437

Savage NC, Howell W and Mapletoft RJ (1987) Superovulation in the cow using estradiol $17 \beta$ or GnRH in conjunction with FSH-P Theriogenology 27 383-394

Vos PLAM, van der Schans A, de Wit AAC, Bevers MM, Willemse AH and Dieleman SJ (1994) Effects of neutralization of pregnant mares' serum gonadotrophin (PMSG) shortly before or at the preovulatory LH surge in PMSG-superovulated cows on follicular function and development Journal of Reproduction and Fertility 100 387-393

Voss HJ, Allen SE, Foote RH Im P, Kim CK and Aquadro P (1989) Buserelin in a superovulatory regimen for Holstein cows. I. Pituitary and ovarian hormone response in an experimental herd Theriogenology 31 371-384

Walton JS and Stubbings RB (1986) Factors affecting the yield of viable embryos by superovulated Holstein-Friesian cows Theriogenology 26 167-177

Wubishet A, Graves SL, Spahr DJ, Kesler DJ and Favero RJ (1986) Effects of $\mathrm{GrRH}$ on superovulatory responses of dairy cows Theriogenology 25 423-427

Yadav MC, Walton SJ and Leslie KE (1986) Plasma concentrations of luteinizing hormone and progesterone during superovulation of dairy cows using follicle stimulating hormone or pregnant mare serum gonadotrophin Theriogenology 26 523-540 